\title{
Transient remission of pre-existing left bundle branch block during general anesthesia in a centenarian
}

\author{
Takeaki Shiga', Takashi Suzuki ${ }^{1 *} \mathbb{D}$, Masayuki Somei $^{2}$ and Noriko Okumura ${ }^{1}$
}

Keywords: Left bundle branch block, Remission, Centenarian, General anesthesia, Hip fracture, Heart rate, Blood pressure

We present a case of a centenarian patient in whom preexisting left bundle branch block (LBBB) transiently reverted to normal ventricular conduction during general anesthesia. A 104-year-old woman with a history of hypertension, chronic heart failure, and cognitive impairment was admitted for surgical repair of a femoral neck fracture. The standard 12-lead electrocardiogram (ECG) on admission revealed left axis deviation and complete LBBB with a heart rate (HR) of $60 \mathrm{bpm}$. Echocardiography indicated left ventricular dyssynchrony with an ejection fraction of $51 \%$. Due to her restless and agitated behavior, general anesthesia was selected for surgery.

On arrival in the operating room, the patient's blood pressure (BP) was $170 / 110 \mathrm{mmHg}$ and HR was $110 \mathrm{bpm}$ with a regular rhythm. ECG monitoring showed a wide QRS complex (140 ms) with RsrS pattern (Fig. 1a). Anesthesia was induced with fentanyl, remifentanil, propofol, and rocuronium, followed by insertion of a supraglottic airway, and maintained with desflurane, remifentanil, and fentanyl. Her lungs were mechanically ventilated. Twenty minutes after the commencement of anesthesia, the QRS complex abruptly narrowed to an $\mathrm{rSr}^{\prime}$ pattern $(80 \mathrm{~ms})$ with a $\mathrm{HR}$ of $80 \mathrm{bpm}$ and BP of 100/50 mmHg (Fig. 1b). Surgery was commenced after femoral nerve block using levobupivacaine.

Intraoperatively, $\mathrm{HR}, \mathrm{BP}, \mathrm{S}_{\mathrm{P}} \mathrm{O}_{2}$, and end-tidal $\mathrm{CO}_{2}$ were maintained at $50-80 \mathrm{bpm}, 90 / 40-120 / 60 \mathrm{mmHg}$, $99-100 \%$, and $32-43 \mathrm{mmHg}$, respectively. At the end of the surgery that lasted for $33 \mathrm{~min}$, the QRS complex widened to an RSr pattern (140 ms) at a HR of $50 \mathrm{bpm}$ and $\mathrm{BP}$ of $100 / 60 \mathrm{mmHg}$ (Fig. 1c) for a few minutes.

\footnotetext{
*Correspondence: tksuzuki@med.showa-u.ac.jp

'Department of Anesthesiology, Showa University Koto Toyosu Hospital,

5-1-38, Toyosu, Koto-ku, Tokyo 135-8577, Japan

Full list of author information is available at the end of the article
}

Next, during the extubation phase, which was immediately after the reversal of neuromuscular block by sugammadex, QRS morphology changed to an RsrS pattern with the same QRS duration $(140 \mathrm{~ms})$. HR and BP at this time were $75 \mathrm{bpm}$ and 170/100 mmHg (Fig. 1d). A 12-lead ECG performed 6 days postoperatively showed LBBB at a HR of $64 \mathrm{bpm}$, comparable to that in the preoperative period. The patient developed postoperative pneumonia requiring extended hospitalization and was discharged to a nursing home on the 28th postoperative day.

LBBB is commonly associated with structural heart disease and left ventricular dysfunction and is thought to increase cardiac mortality in patients with congestive heart failure [1]. LBBB can occur in a transient or intermittent manner, developing under diverse clinical settings, including during anesthesia, due to various etiologies such as blood pressure perturbation, tachycardia, and bradycardia. Conversely, the episodic disappearance of LBBB during anesthesia has rarely been reported [2-4]. The presented case shares similarities with three such previously reported cases, as summarized in Table 1. The disappearance of the LBBB shortly after induction of anesthesia and the reappearance during or immediately after emergence from anesthesia are mostly common characteristics of these cases with a partially exceptional case reported by Garcia et al. These cases suggest that sufficient vasodilatory effects of volatile anesthetics and negative chronotropic effects of narcotics might contribute to remission.

The choice of anesthesia technique for hip fracture fixation in elderly patients has been discussed [5]. We speculate, although with our limited experience and from previous reports, that appropriate general anesthesia possibly has positive impacts on ventricular conduction delay in even centenarian patients with LBBB. 

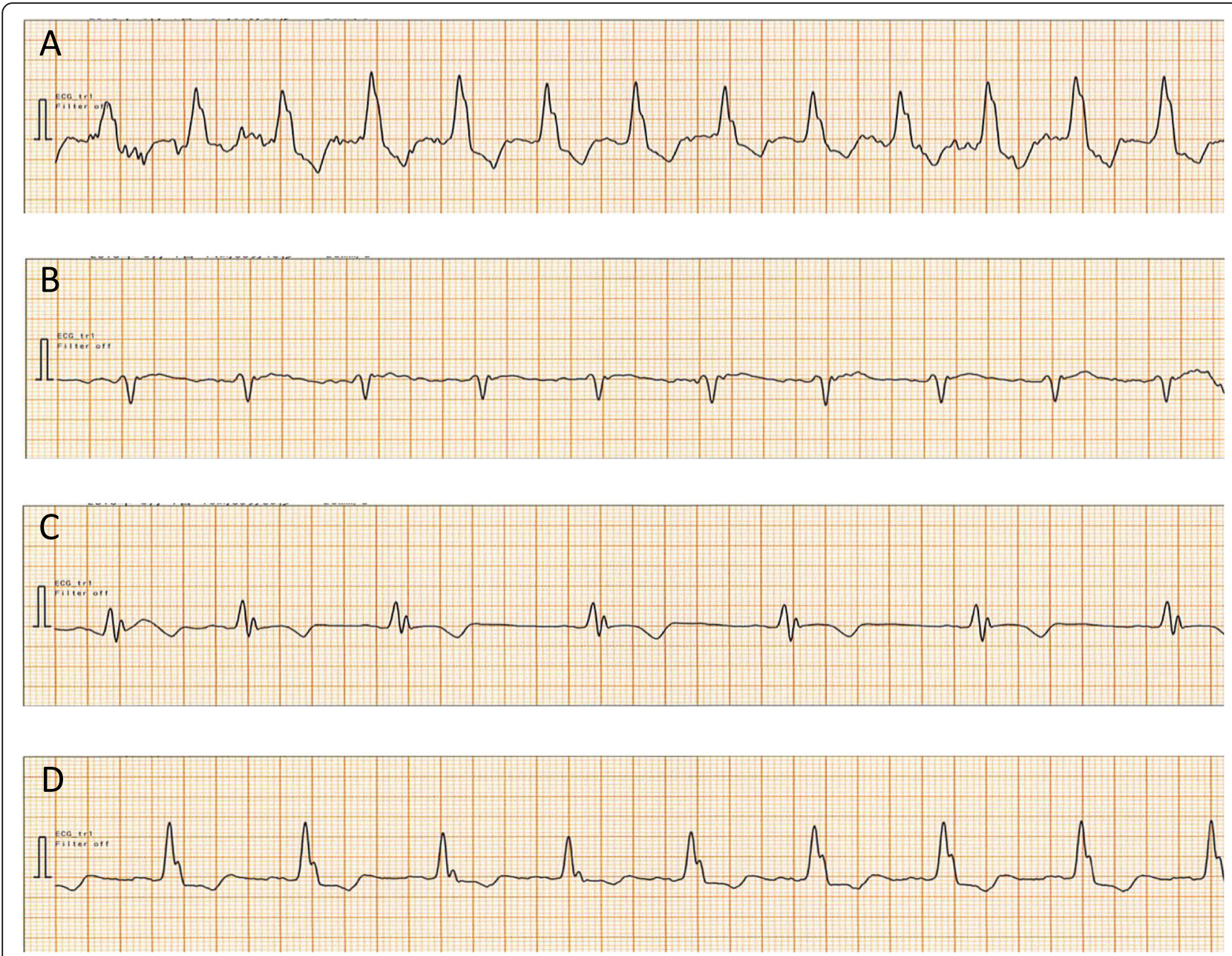

Fig. 1 Chronological changes in QRS complex morphology recorded on a patient monitor (CM5) during anesthesia. a Immediately before anesthesia induction. $\mathbf{b} 20 \mathrm{~min}$ after the start of anesthesia. $\mathbf{c}$ End of surgery. $\mathbf{d}$ During extubation

Table 1 Previously reported cases of transient remission of pre-existing left bundle branch block during general anesthesia

\begin{tabular}{|c|c|c|c|c|c|c|c|c|}
\hline References & $\begin{array}{l}\text { Age/ } \\
\text { sex }\end{array}$ & Comorbidities & $\begin{array}{l}\text { Surgical } \\
\text { procedure }\end{array}$ & $\begin{array}{l}\text { Induction } \\
\text { agents }\end{array}$ & $\begin{array}{l}\text { Maintenance } \\
\text { agents }\end{array}$ & $\begin{array}{l}\text { Elapsed time from anesthesia } \\
\text { induction to LBBB remission (min) }\end{array}$ & $\begin{array}{l}\text { Situation at LBBB } \\
\text { reappearance }\end{array}$ & $\begin{array}{l}\text { Suspected cause } \\
\text { of remission }\end{array}$ \\
\hline \multirow{3}{*}{$\begin{array}{l}\text { Garcia } \\
\text { et al. } \\
\text { (1997) [2] }\end{array}$} & \multirow[t]{3}{*}{$58 / \mathrm{M}$} & \multirow[t]{3}{*}{ Hypertension } & \multirow{3}{*}{$\begin{array}{l}\text { Inguinal } \\
\text { hernia repair }\end{array}$} & Thiopental & Enflurane & \multirow[t]{3}{*}{15} & \multirow{3}{*}{$\begin{array}{l}\text { Sustained } \\
\text { remission* }\end{array}$} & \multirow{3}{*}{$\begin{array}{l}\text { Blood pressure } \\
\text { reduction }\end{array}$} \\
\hline & & & & Fentanyl & Nitrous oxide & & & \\
\hline & & & & Suxamethonium & Atracurium & & & \\
\hline \multirow{3}{*}{$\begin{array}{l}\text { Mishra } \\
\text { et al. } \\
\text { (2009) [3] }\end{array}$} & \multirow[t]{3}{*}{$45 / F$} & \multirow[t]{3}{*}{ Hypertension } & \multirow[t]{3}{*}{ Mastectomy } & Propofol & Isoflurane & \multirow[t]{3}{*}{$25^{+}$} & \multirow{3}{*}{$\begin{array}{l}\text { On reversal of } \\
\text { neuromuscular } \\
\text { block }\end{array}$} & \multirow{3}{*}{$\begin{array}{l}\text { Heart rate } \\
\text { reduction }(<60 \text { bpm) }\end{array}$} \\
\hline & & & & Fentanyl & Nitrous oxide & & & \\
\hline & & & & Vecuronium & & & & \\
\hline \multirow{3}{*}{$\begin{array}{l}\text { Silva et al. } \\
\text { (2017) [4] }\end{array}$} & \multirow[t]{3}{*}{$73 / F$} & \multirow{3}{*}{$\begin{array}{l}\text { Hypertension, bronchial } \\
\text { asthma, diabetes mellitus (type II) }\end{array}$} & \multirow{3}{*}{$\begin{array}{l}\text { Exploratory } \\
\text { laparotomy }\end{array}$} & Propofol & Sevoflurane & \multirow[t]{3}{*}{$30^{\ddagger}$} & \multirow{3}{*}{$\begin{array}{l}\text { On arrival in the } \\
\text { PACU }\end{array}$} & \multirow{3}{*}{$\begin{array}{l}\text { Heart rate } \\
\text { reduction }(<75 \text { bpm) }\end{array}$} \\
\hline & & & & Remifentanil & Remifentanil & & & \\
\hline & & & & Rocuronium & & & & \\
\hline \multirow{4}{*}{$\begin{array}{l}\text { Present } \\
\text { case }\end{array}$} & \multirow[t]{4}{*}{$104 / F$} & \multirow{4}{*}{$\begin{array}{l}\text { Hypertension, chronic heart } \\
\text { failure, cognitive impairment }\end{array}$} & \multirow{4}{*}{$\begin{array}{l}\text { Femoral neck } \\
\text { fracture } \\
\text { fixation }\end{array}$} & Propofol & Desflurane & \multirow[t]{4}{*}{20} & \multirow{4}{*}{$\begin{array}{l}\text { During the } \\
\text { extubation } \\
\text { period }\end{array}$} & \multirow{4}{*}{$\begin{array}{l}\text { Blood pressure } \\
\text { reduction }\end{array}$} \\
\hline & & & & Remifentanil & & & & \\
\hline & & & & Fentanyl & Remifentanil & & & \\
\hline & & & & Rocuronium & & & & \\
\hline
\end{tabular}

LBBB left bundle branch block, $M$ male, $F$ female, $P A C U$ postanesthesia care unit

* Sustained remission was reconfirmed 1 month postoperatively

${ }^{+}$LBBB disappeared again for $10 \mathrm{~min}$ during postoperative observation for $1 \mathrm{~h}$

${ }^{\ddagger}$ Bronchospasm occurred during induction of anesthesia and was successfully treated with inhalation of salbutamol and ipratropium 


\section{Abbreviations}

ECG: Electrocardiogram; HR: Heart rate; BP: Blood pressure; LBBB: Left bundle branch block; $\mathrm{SpO}_{2}$ : Arterial oxygen saturation

\section{Acknowledgements}

Not applicable.

\section{Authors' contributions}

MS and TSh conducted the anesthetic management of the patient. TSh wrote the original draft. Tsh and NO prepared the figure. TSh obtained the consent for publication. TSu wrote the final manuscript. All authors reviewed and approved the final manuscript for submission.

\section{Funding}

Internal departmental funding

\section{Availability of data and materials}

Please contact the corresponding author to request data access.

\section{Ethics approval and consent to participate}

In our institution, the publication of case reports is exempted from Ethics Committee approval.

\section{Consent for publication}

Written informed consent was obtained from the patient's next of kin for publication of this case report.

\section{Competing interests}

The authors declare that they have no competing interests.

\section{Author details}

'Department of Anesthesiology, Showa University Koto Toyosu Hospital, 5-1-38, Toyosu, Koto-ku, Tokyo 135-8577, Japan. ${ }^{2}$ Department of Intensive Care Medicine, Showa University School of Medicine, 1-5-8 Hatanodai, Shinagawa-ku, Tokyo 142-8666, Japan.

Received: 8 August 2019 Accepted: 24 September 2019 Published online: 24 October 2019

\section{References}

1. Bazoukis G, Tsimos K, Korantzopoulos P. Episodic left bundle branch block-a comprehensive review of the literature. Ann Noninvasive Electrocardiol. 2016;21:117-25.

2. Garcia EJ, Kumar CM, Lawler PG, Newnam PT. Spontaneous remission of left bundle branch block during anesthesia. Anaesthesia. 1997;52:684-7.

3. Mishra S, Nasa P, Goyal GN, Khurana H, Gupta D, Bhatnagar S. The rate dependent bundle branch block -- transition from left bundle branch block to intraoperative normal sinus rhythm. Middle East J Anaesthesiol. 2009;20:295-8.

4. Silva AMOCD, Silva EAGLD. Intermittent left bundle branch block - reversal to normal conduction during general anesthesia. Rev Bras Anestesiol. 2017; 67:430-4.

5. Van Waesberghe J, Stevanovic A, Rossaint R, Coburn M. General vs neuraxial anaesthesia in hip fracture patients: a systematic review and meta-analysis. BMC Anesthesiol. 2017:17:87.

\section{Publisher's Note}

Springer Nature remains neutral with regard to jurisdictional claims in published maps and institutional affiliations.

\section{Submit your manuscript to a SpringerOpen ${ }^{\circ}$ journal and benefit from:}

- Convenient online submission

- Rigorous peer review

- Open access: articles freely available online

High visibility within the field

Retaining the copyright to your article

Submit your next manuscript at $\boldsymbol{\nabla}$ springeropen.com 